\title{
Technology adoption in Malaysian schools: An analysis of national ICT in education policy initiatives
}

\author{
Azlin Zaiti Zainal \\ azlinzainal@um.edu.my \\ Universiti Malaya, Malaysia \\ Siti Zaidah Zainuddin \\ zaidah75@um.edu.my \\ Universiti Malaya, Malaysia
}

\begin{abstract}
Educational change, particularly change involving the adoption of educational innovations, is a complex process. In Malaysia, the significant role of information and communication technologies (ICTs) in promoting digital education is reflected in the national ICT in education policy. Nevertheless, studies in the Malaysian educational context have shown that the policy implementation resulted in varying degrees of success. Through a discourse analysis approach, this paper aims to examine the research studies on large-scale initiatives introduced to digitize the Malaysian education system, from the Smart Schools program to the incorporation of the Frog Virtual Learning Environment (VLE) in the classroom. The rationale behind these top-down initiatives and how they affected the stakeholders at the micro level, namely, teachers and students, are reviewed and analyzed. The analysis informs our understanding of the factors that contribute to the successful and unsuccessful implementation of these initiatives and guide the planning of future policies.
\end{abstract}

\section{Keywords}

Technology; Education policy; Literature review; Discourse analysis-based research synthesis 


\section{Introduction}

Pettersson's (2018) review indicates that research has tended to overlook the wider contextual factors affecting teachers' integration of technology and focused more on teachers' competencies in ICT use. It is argued that although teachers can develop their individual competencies in ICT use, it is imperative to seek ways to disseminate effective uses of ICT to support their use on a wider scale and in directing the change (Agélii Genlott, Grönlund \& Viberg, 2019). It is especially crucial to consider the enabling factors of technology use in schools and also consider the reasons why some initiatives are more successful than others within the context of implementation. Comparative studies on the impact of ICT in education policies are useful in illustrating the factors that contribute to the effective implementation of policies (Plomp, Anderson, Law \& Quale, 2009). Nevertheless, it is more common to find studies conducted in the western context compared to developing countries. As argued by TolaniBrown, McCormac and Zimmermann (2011, p.219) "the context for studies in North America and Europe is very different from the social, economic and cultural realities often found within communities in developing countries" due to the differing resources available and the goals to be achieved. They further suggest the importance of understanding the host of factors that facilitate or mitigate ICT effects on students' learning in making decisions about policy implementation. This study aims to explore the influence of ICT in education policy on two different projects that integrate ICT in the teaching and learning process.

\section{a. Factors affecting effective ICT in education implementation}

Related to the complexity of educational change are issues associated with factors that influence the implementation of new educational initiatives. As Younie (2006) has argued, the implementation of ICT policy can be observed at macro (national agencies), meso (regional agencies) and micro (schools and teachers) levels, and the multifaceted nature of implementation is one of the reasons why it is difficult to obtain the desired impact. The challenges to ICT implementation have also been discussed at length (Mumtaz, 2000; Pelgrum, 2001). One way of discussing the barriers is by looking at the external and internal factors of teachers or first and second order barriers (Ertmer, 1999; Eteokleous, 2008). Factors external to the teacher or first order barriers such as the quality of ICT training and opportunities to undergo training, the technical support available, the inadequacy of the infrastructure, school policies and leadership can influence the success of ICT policies in schools. Nevertheless, factors internal to the teacher or second order barriers such as competence in ICT, belief systems and teaching philosophies, also play a role in determining the success of any policy and policy makers should understand the interrelationships between these factors. Eickelmann and Vennemann (2017) argued that "external factors or barriers could be altered by allocating additional resources to schools, for example by equipping them with a sufficient number of computers and software programs or by providing additional computer training for teachers" (p.734). They also stressed that internal factors are much more complicated to change when enhancing the use of ICT.

Research has shown that teachers' use of technology in teaching is related to their beliefs about the value of technology (Coppola, 2004; Lam, 2000; Ottenbreit-Leftwich, Glazewski, Newby, \& Ertmer, 2010; Snoeyink and Ertmer, 2001; Zhao, Pugh, Sheldon \& Byers, 2002). Furthermore, research has also indicated that there is a discrepancy between teachers' perceptions of the value of technology and how ICT can be integrated in classrooms. A recent study by Eickelmann and Vennemann (2017) which compared teachers from three different European countries indicate that these teachers' beliefs and attitudes regarding technology differed between the three countries. 
Recent literature highlights the divide in terms of educational setting including the rural and urban areas (Howley, Wood \& Hough, 2011; Kale \& Goh, 2014; Kormos, 2018; Wood \& Howley, 2012). Kale and Goh's (2014) study on teachers from rural and urban areas revealed that despite holding similar beliefs about technology integration and having the same access to Web 2.0 tools, the rural teachers made little use of these tools compared to urban teachers. In Kormos' (2018) study, a comparison of urban, rural and suburban teachers' use of web-based applications showed these tools were utilized more by suburban teachers compared to teachers from the other two groups. Wood and Howley (2012) found that suburban teachers' use of technology were more sophisticated compared to teachers from rural or urban schools. Howley, Wood and Hough (2011) compared rural and urban teachers' attitudes towards technology and found that the former tended to have more positive attitudes towards technology. Despite having positive attitudes, it was found that these teachers did not regularly use technology due to limited access to technology. While understanding barriers to implementation is critical in policy implementation, it is also important to understand how successful implementation can be achieved and sustained through monitoring and evaluation ( $\mathrm{M} \& \mathrm{E}$ ) programs.

\section{b. Monitoring and evaluation of ICT in education initiatives}

To examine the effects of policy related to educational programs, it is important for governments to monitor their implementation and evaluate their effectiveness. As suggested by Tolani-Brown et al., (2011) "[p]rogram evaluation is an essential component to the implementation of effective educational interventions, especially those that employ innovative technologies" (p.232). Nevertheless, it is important to recognize the distinction between program evaluation and research. Hamilton and Feldman (2014) argued that although the methods and procedures used in program evaluation may be similar to the methods and procedures used in research, the goals between research and program evaluation are essentially different. They suggest that research on programs places an emphasis on theoretical gaps or specific knowledge areas unlike program evaluation where the emphasis is on quality of a particular program.

To understand how the goals differ, it is useful to refer to Dale's (1986) idea of purpose or what he terms 'projects'. Three types of policy projects were proposed by Dale, namely, social administration, policy analysis and social science. The first of these was conceptualized within the context of the welfare state in England from the 1940s to the 1970s where the purpose of the research is to improve administrative practice. The second 'project', policy analysis, is to discover ways of delivering social policies effectively and efficiently despite the content of the policy. To put it simply, the researcher's task is more about identifying the problems in policy implementation and recommending appropriate solutions. Policy within this project is defined as "the function and preserve of the government" (Ozga, 2000 , p. 39). This is different from the social science project, which is not about trying to ensure things work as intended but is rather to understand how things actually work (Dale, 1986).

It is further argued that a fundamental difference between the latter two projects is the clients. A policy analysis project is concerned with the problem that is defined based on the framework of the client or the policy makers where the researcher is focused on strategic concerns and the problem is defined according to the client's definition. The policy analysis project tends to be associated with the post-positivist tradition. As pointed out by Greene (2007), "post-positivist, quantitative evaluation characteristically provides information on the degree to which a given social or educational intervention attained intended outcomes established by decision makers and program developers" (p.40). The measured outcomes will then be used by policy makers to further set the course of action to solve the problems discovered in the study. 
In contrast, the social science project is orientated towards the academic arena rather than the clients' needs. This is because the definition of the 'problem' will not be based on the clients' definition but rather on 'the nature of existing theory' and is orientated towards improving the theory. However, Ozga (2000) warns against maintaining strict definitions. Within a social science project we also see how clients' needs - for example, teachers' needs - can be addressed through constructivist approaches such as interpretivism and critical theory. What we can draw from interpretivist, qualitative evaluation is "the quality and meaningfulness of program experience, from the multiple perspectives of program staff, participants, and associated family and community members" (Greene, 2007 , p. 41). The 'project' adopted in this study was mainly based on the social science project. The current research was not conducted as part of the official government project on program evaluation but rather from the lens of independent researchers working on an area of education policy. The aim is to contribute further towards an understanding of the academic field of ICT in education policy. However, it is also recognized that the findings will be useful for policy makers in terms of the planning of initiatives and provision of future training programs. This brings us to the next section on how impact is measured.

\section{c. Measuring impact of ICT education policies}

It is important to understand how impact has been conceptualized in the literature before embarking on an impact study. Hawkey highlights the definition of impact in his review of impact theory in educational research:

Impacts (also referred to as effects) may be planned or unplanned; positive or negative; achieved immediately or only after some time; and sustainable or unsustainable $\ldots$ Impacts may be observable/measurable during implementation, at project completion, or only some time after the project has ended. Different impacts may be experienced by different stakeholders. (Hawkey, 2006, p. 2)

The definition points to the many facets of 'impact' and raises issues that need to be addressed in conducting impact studies. They include the nature of impact, when to conduct an impact study and the types of impact experienced by different stakeholders.

As highlighted earlier, similar to research on the impact of educational interventions, program evaluation studies on ICT programs can employ either quantitative or qualitative methods or both. The data collected will need to be systematic and consider the varying factors involved in policy implementation. Researchers would need to be aware of the strengths or weaknesses of a particular approach. For example, qualitative case descriptions while rich and informative, will not give a broad picture of the impact of policy implementation. According to Tolani-Brown et al. (2011), an advantage of qualitative approaches, however, is that they "provide the foundation for higher-level, advanced statistical analyses and more complex evaluation designs that are needed to assess whether an ICT indeed causes a particular learning or other education related outcome" (p.222). They also propose that a sound conclusion can be obtained from evidence-based research findings that utilized rigorous experimental approach to data collection. Nevertheless, they also acknowledge that such experimental studies can be challenging to conduct in developing countries "given their costs in developing country contexts where resources are scarce-highlighting one of the many challenges to rigorous [monitoring and evaluation] M\&E efforts related to ICTs and education in developing countries" (p.222). 
Quantitative measurement of achievements such as benchmarking and quantitative indicators are useful to illustrate to what extent the predetermined goals have been achieved. However, it can be limiting in the sense that they do not provide an understanding of the complexity of implementation. They are useful in providing us with information on what is achieved based on predetermined criteria but are not able to capture the complexity of the contextual variables that influence stakeholders' responses towards the policy. Furthermore, research on ICT education programs in the context of developing countries have often looked at the impact of specific programs implemented in a specific country and not a comparative analysis of the different initiatives implemented in a country. This analysis aims to fill the gap by comparing two different ICT in education programs and how teachers and students respond to them to understand the influences of implementation and their effectiveness in digitizing the nation's education system.

\section{The Malaysian Smart School}

A clear rationale as to why a certain policy is introduced is crucial. In the context of ICT in education, without a clear rationale, "[p]olicy becomes techno-centric, promoting the purchase of equipment or the training of teachers without providing a strong educational purpose or goal for the use of technology" (Kozma, 2008, p.1084). In the Malaysian context, one of the recent ICT in education policies is enacted through the implementation of the Smart Schools. The main aim of these Smart Schools is to develop and equip students in becoming an effective workforce in order to meet the challenges of the 21 st century. Such a project entails education "that stimulates thinking, creativity, and caring for all students, caters to individual differences and learning styles, and is based on more equitable access (Chan, 2002, p.3).

The introduction of the Smart School concept into schools implies that ICT will play a significant part in school management and classroom practice. The Smart School curriculum promotes the utilization of differentiated teaching approaches to cater for the different academic levels of learners. It also highlights the need to bring meaningful activities into the classroom through ICT that would promote a learner-centred approach. With the implementation of Smart Schools, the "processes relating to curriculum, pedagogy, assessments, and teaching learning materials (TLMs), are reinvented to help students learn more effectively and efficiently" (MDC, 2005, p. 7). It is apparent that the use of ICT in the classroom as proposed by the Smart School roadmap was intended to transform teaching and learning.

It is also important to locate this education policy with regard to the larger national ICT policy as a policy is not created devoid of context and its gestation is often based on the antecedent policies (Taylor et al., 1997). As stated earlier, the impetus for change in Malaysia can be attributed to the need to fulfil the nation's economic aspirations. The context in which ICT in education policy is produced is in line with the National ICT Master Plan. The Multimedia Super Corridor (MSC) was created under this Master Plan and comprises seven flagship applications. One of the flagship applications includes a focus of education in the form of the Smart School project. Smart Schools were launched in July 1997 as one of the Multimedia Supercorridor's Flagship Applications. After completing the pilot of 88 schools in 2002, the Ministry of Education worked with other agencies on the rolling-out phase of the Smart School concept, materials, skills and technologies to regular schools nationwide.

\section{BestariNet project}

Through the 1BestariNet initiative, the government has invested heavily in infrastructure that could connect the 10,000 primary and secondary schools in Malaysia. The rationale for the implementation 
of the project includes to increase ICT access to learners and reinvent teaching and learning. Teaching and learning could be conducted in a cloud-based learning environment through the Frog VLE platform, a Learning Management System (LMS) introduced by a UK company. Under this project, teachers were also supplied with smartphones. The use of mobile devices such as tablets and smartphones supported with high speed internet connection is supposed to support transformative pedagogy where teachers can teach synchronously and parents can also be involved in monitoring their children's progress.

It is important to understand how the 1BestariNet project differs from the Smart School project. A key difference is that Frog VLE is a cloud-based platform that enables a massive storage of learning materials. The platform mirrors real world classroom-based teaching in many ways except that all teaching and learning and classroom management processes are conducted through the platform. Students and teachers, therefore, have access not only to the learning materials uploaded that are shared online but also a host of Google applications. This idea of enabling access to a wide variety of learning applications to all schools is an ambitious one, one that could potentially help to reduce the gap between the rural and urban schools. Such implementation, however, will require a further investigation in order to understand how teachers respond towards this initiative. Malaysia is made up of 14 states altogether and there are a number of districts within a state. These states differ in terms of their geographical features and landscape where some areas are more developed than others. As highlighted in previous studies, teachers from rural and urban backgrounds differ in terms of their use of technology despite having similar attitudes towards technology.

For the past decade, studies have focused on the impact of these initiatives on teaching and learning from various approaches. However, studies comparing ICT utilization particularly in the context of the two different ICT in education programs are lacking. Therefore, the current study aims to answer the following research questions.

1) What are teachers' perceptions of the Malaysian ICT in education initiatives?

2) How do the Malaysian ICT in education initiatives impact students' learning?

\section{Methodology}

\section{a. Research approach}

This study analyses the impact of two major educational ICT educational programs through a literature review approach. The approach taken in conducting the literature review is guided by a process that Onwuegbuzie and Frels (2014) refer to as Discourse Analysis-Based Research Synthesis (DARS). This framework was developed based on Gee's (2010) discourse analysis and is applicable in this study as it offers "a theoretical framework for observing social reality via the extant literature" (Onwuegbuzie and Frels, 2014, p.56). In the context of the literature review, the research literature represents bodies of knowledge and it does not serve the interest of the reviewer to refer to only one source of research literature. The link between these bodies of knowledge, new knowledge forms and new modes of knowledge dissemination all constitute discourse over time (Phillips \& Hardy, 2002).

Bearing in mind, this study is not concerned with measuring the effectiveness of ICT in education programs based on predefined goals (a strategy commonly associated with outcome-oriented approach) but rather, aims to understand how stakeholders respond to two different programs. Specifically, this study focuses on the individual processes in terms of the teachers and students' 
response to the initiatives instead of examining the processes of the implementation of the two initiatives. Based on the focus of the study, the discourse analysis through a literature review approach is applicable because the researchers can examine how the 'social reality' (Onwuegbuzie \& Frels, 2014) is described, constructed and interpreted through the discourses in the literature. The social reality in this case is the practices realized by either actions involving pedagogical uses of ICT or experiences in using ICT for general and pedagogical purposes by the various stakeholders within the educational context. The epistemological view of this study is different from other studies as it adopts the interpretivist stance in analyzing the impact of the educational initiatives which is in line with Greene's (1994) interpretivist orientation to program evaluation. This approach provides added value in terms of evaluating the building tasks of language (Gee, 2010) at every component of the literature of empirical studies including the theoretical and conceptual framework and the rigorous and comprehensive methodological approach.

The use of discourse analysis which is mapped onto the literature review is, again, very much applicable because it involves comparing and contrasting information contained in two or more works. Reviewers also should "make reference to the social context in which these bodies of knowledge are extracted and the discourses are produced" (Onwuegbuzie \& Frels, 2014, p.57). In the case of the current research, the social context refers to the implementation of two different ICT in education policy initiatives in Malaysian primary and secondary schools. By applying DARS in the review of literature related to these initiatives, the relevant bodies of knowledge would be examined where this would inform our understanding of the impact of the implementation of these policy initiatives. The approach taken in this study is a between-study analysis as opposed to a within-study analysis alone. While the former involves comparing the findings of two or more literature sources, the latter includes a detailed and thorough analysis of the contents of a particular source.

\section{b. Research procedures}

The study adapted Frel's (2010) search phases in conducting DARS. In order to compare the research findings of different works, criteria for selecting sources were established prior to searching and identifying research articles to be included in the analysis. In conducting a literature review, the researcher would need to examine the key findings and the interpretation of the studies reviewed. Gee's discourse analysis involving seven building tasks of language can be mapped onto this stage of the literature review process. The building tasks that Gee proposed are in line with the social constructionist perspective as they are based on the premise that language is constantly in interaction with situations and that humans construct reality based on the language used in a particular situation.

\section{c. Data sources}

\section{Identification of sources}

As this study aims to look at the impact of ICT in education policy implementation, studies on Smart Schools and 1BestariNet project involving teachers and learners were included in the bibliographic search. These comprise aspects such as students' perceptions and/or attitudes to technology, teachers' perceptions and/or attitudes of technology, experimental/non-experimental studies on students' attitudes or achievement, observation of the teaching process, and professional development of teachers. Studies on teachers' professional development programs related to these initiatives are included in this study as previous studies have shown that professional development programs play an important role in influencing teacher's perceptions and use of technology. The review only considers research findings based on data collected from primary and secondary schools. Studies that focused 
on school managers, Headmasters and IT coordinators as well as perceptions of instructors from higher education were excluded.

It was decided that only published research articles or book chapters which were based on empirical evidence would be included in the review. Review studies, conference proceedings, and Masters or $\mathrm{PhD}$ theses were all excluded from the analysis. The application of the criteria resulted in the identification of 25 relevant literature sources for analysis. Table 1 presents studies that examined the Smart School project. Based on the criteria, seven studies have been identified. Studies which observe the 1BestariNet project are prevalent amongst researchers. Table 2 shows a total of 18 studies and most of these studies focus on the aspect of teachers' perceptions of technology.

\begin{tabular}{llll}
\hline Aspects & $\begin{array}{l}\text { No. of Author(s) } \\
\text { articles }\end{array}$ & Type of Study Location
\end{tabular}

\begin{tabular}{l}
\hline Students' \\
perceptions \\
and/or attitudes \\
to technology
\end{tabular}

to technology

$\begin{array}{lll}\text { Ong and } & \text { Mixed methods } \\ \text { Ruthven } & \text { Qualitative:classroom observation, } \\ (2010) & \text { teacher interview and student } \\ & \text { report } \\ & \text { Quantitative: Questionnaire }\end{array}$

Two Smart

schools in

Penang and

Perak :

Mainstream schools nearby to each Smart school

Teachers'
perceptions
and/or attitudes
to technology

3

Kuala Langat

District in Selangor $\begin{array}{ll}\text { Thang et } & \text { Qualitative: teacher interviews and Kuala Lumpur } \\ \text { al. (2010) } & \text { mentor reflections }\end{array}$

\begin{tabular}{llll}
\hline $\begin{array}{l}\text { Experimental/non } \\
\text { experimental } \\
\text { studies on } \\
\text { students' } \\
\text { attitudes or } \\
\text { achievement }\end{array}$ & $\begin{array}{l}\text { Ong and } \\
\text { Ruthven } \\
(2009)\end{array}$ & $\begin{array}{l}\text { Quantitative: Quasi-experimental } \\
\text { design; Questionnaire }\end{array}$ & $\begin{array}{l}\text { The states of } \\
\text { Penang and }\end{array}$ \\
Perak
\end{tabular}




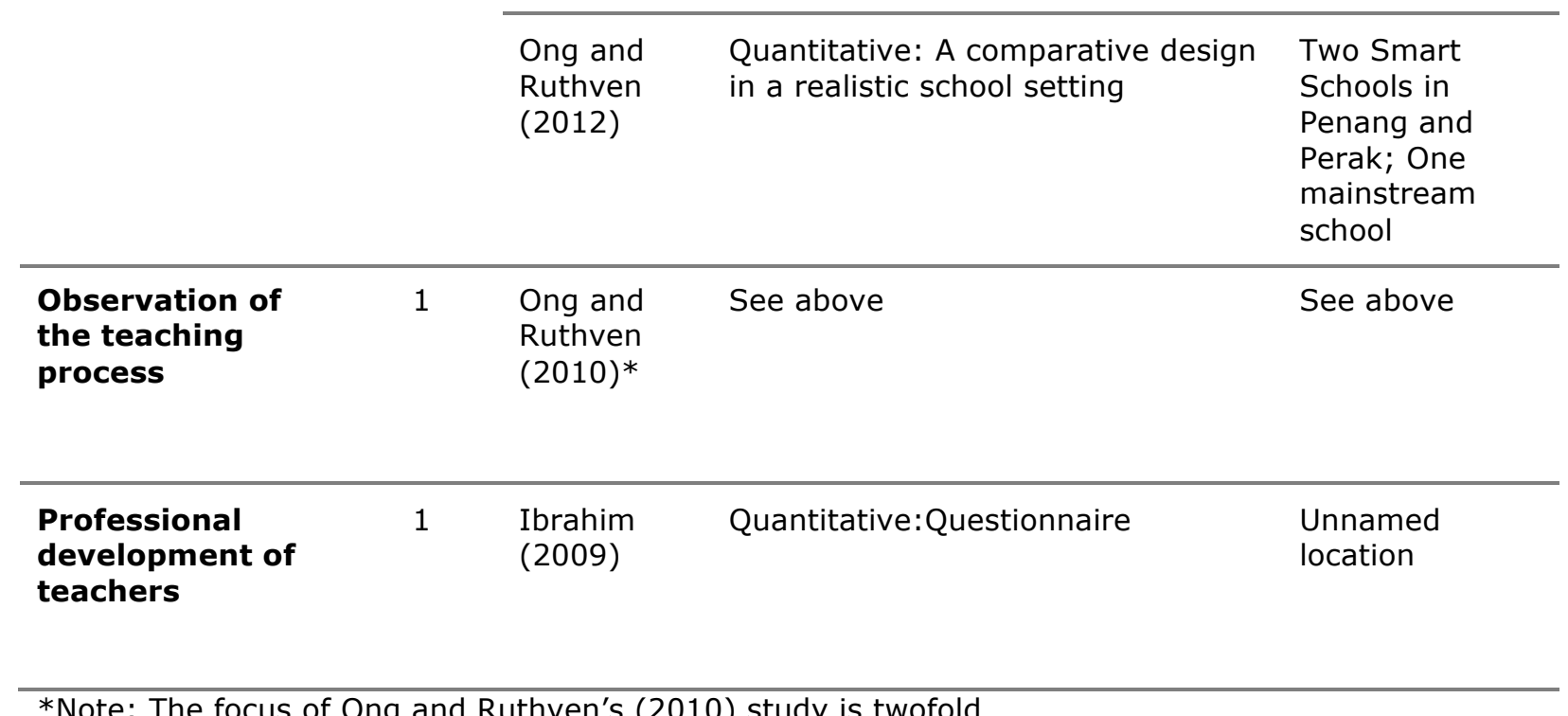

*Note: The focus of Ong and Ruthven's (2010) study is twofold

Table 1: Studies related to Smart School initiative

\begin{tabular}{|c|c|c|c|c|}
\hline Aspects & $\begin{array}{l}\text { No. of } \\
\text { articles }\end{array}$ & Author(s) & Type of study & Location \\
\hline \multirow{4}{*}{$\begin{array}{l}\text { Students' } \\
\text { perceptions } \\
\text { and/or } \\
\text { attitudes to } \\
\text { technology }\end{array}$} & 4 & $\begin{array}{l}\text { Abdul Majid and } \\
\text { Che Hasim (2019) }\end{array}$ & Quantitative: Survey & $\begin{array}{l}\text { Shah Alam in } \\
\text { Selangor }\end{array}$ \\
\hline & & Lim et al. (2018) & $\begin{array}{l}\text { Quantitative: } \\
\text { Questionnaire }\end{array}$ & $\begin{array}{l}\text { Tangkak District in } \\
\text { Johor }\end{array}$ \\
\hline & & $\begin{array}{l}\text { Kamalludeen } \\
\text { (2016) }\end{array}$ & $\begin{array}{l}\text { Quantitative: } \\
\text { Questionnaire }\end{array}$ & $\begin{array}{l}\text { Taman Melawati in } \\
\text { Kuala Lumpur }\end{array}$ \\
\hline & & Thah (2014) & $\begin{array}{l}\text { Quantitative: } \\
\text { Questionnaire }\end{array}$ & $\begin{array}{l}\text { All states throughout } \\
\text { Malaysia }\end{array}$ \\
\hline $\begin{array}{l}\text { Teachers' } \\
\text { perceptions } \\
\text { and/or } \\
\text { attitudes to }\end{array}$ & 15 & $\begin{array}{l}\text { Raman and } \\
\text { Rathanakrishan } \\
\text { (2018) }\end{array}$ & $\begin{array}{l}\text { Quantitative: } \\
\text { Questionnaire }\end{array}$ & $\begin{array}{l}\text { Kuala Muda District } \\
\text { in Kedah }\end{array}$ \\
\hline
\end{tabular}




\section{technology}

Awang et al. (2018)
Mixed-method: Questionnaire; In-depth interview
States of Perlis, Penang, Kedah and Perak

\begin{tabular}{lll}
\hline $\begin{array}{l}\text { Cheok and Wong } \\
\text { (2016) }\end{array}$ & $\begin{array}{l}\text { Qualitative: case study; } \\
\text { Interviews }\end{array}$ & $\begin{array}{l}\text { States of Selangor, } \\
\text { Melaka, Kedah and } \\
\text { Sabah }\end{array}$ \\
&
\end{tabular}

\begin{tabular}{lll}
\hline Cheok (2017) & $\begin{array}{l}\text { Qualitative: Open- } \\
\text { ended questionnaire }\end{array}$ & $\begin{array}{l}\text { Unnamed two } \\
\text { in Malaysia }\end{array}$ \\
\hline $\begin{array}{lll}\text { Hew and Abdul } \\
\text { Kadir (2016a) }\end{array}$ & $\begin{array}{l}\text { Quantitative: } \\
\text { Questionnaire }\end{array}$ & $\begin{array}{l}351 \text { champion } \\
\text { schools** }\end{array}$ \\
\hline
\end{tabular}

\begin{tabular}{lll}
\hline Hew and Abdul & Quantitative: & 351 champion \\
Kadir (2016b) & Questionnaire & schools
\end{tabular}

\begin{tabular}{lll}
\hline $\begin{array}{l}\text { Hew and Abdul } \\
\text { Kadir (2017a) }\end{array}$ & $\begin{array}{l}\text { Quantitative: } \\
\text { Questionnaire }\end{array}$ & $\begin{array}{l}351 \text { champion } \\
\text { schools }\end{array}$ \\
\hline $\begin{array}{ll}\text { Hew and Abdul } \\
\text { Kadir (2017b) }\end{array}$ & $\begin{array}{l}\text { Quantitative: } \\
\text { Questionnaire }\end{array}$ & 50 champion schools \\
\end{tabular}

\begin{tabular}{lll}
\hline Kaur and Hussein & Quantitative: & Northern Seberang \\
$(2015)$ & Questionnaire & Perai district in \\
& Penang
\end{tabular}

\begin{tabular}{lll}
\hline $\begin{array}{l}\text { Mai and Muruges } \\
\text { (2018) }\end{array}$ & $\begin{array}{l}\text { Quantitative: } \\
\text { Questionnaire }\end{array}$ & $\begin{array}{l}\text { Cameron Highlands } \\
\text { in Pahang and } \\
\text { Taiping in Perak }\end{array}$ \\
\hline Yeop et al. (2019) & $\begin{array}{l}\text { Quantitative: } \\
\text { Questionnaire }\end{array}$ & Throughout Malaysia \\
\hline
\end{tabular}

Thah (2014) See above See above

\begin{tabular}{lll}
\hline Yim et al. (2018) & $\begin{array}{l}\text { Quantitative: } \\
\text { Questionnaire }\end{array}$ & $\begin{array}{l}\text { Two Malaysian } \\
\text { states that consisted } \\
\text { of } 19 \text { school districts }\end{array}$
\end{tabular}


Yim et al. (2019) Quantitative:

Questionnaire
Northern Peninsular Malaysia comprising four states

Northern states of Malaysia

\begin{tabular}{|c|c|c|c|c|}
\hline $\begin{array}{l}\text { Experimental/ } \\
\text { non- } \\
\text { experimental } \\
\text { studies on } \\
\text { students' } \\
\text { attitudes or } \\
\text { achievement }\end{array}$ & 1 & $\begin{array}{l}\text { Ramasamy and } \\
\text { Abdul Aziz (2018) }\end{array}$ & $\begin{array}{l}\text { Quantitative: } \\
\text { Experimental study } \\
\text { (pre and posttest); } \\
\text { Questionnaire }\end{array}$ & $\begin{array}{l}\text { Petaling Perdana } \\
\text { district in Selangor }\end{array}$ \\
\hline
\end{tabular}

*Note: The focus of Thah's (2014) study is twofold

**Champion schools are pioneer schools that are trained by FrogAsia as benchmarks for other schools to emulate

Table 2: Studies related to 1 BestariNet initiative

\section{Storing and organizing sources}

Based on an initial review of the sources, they could be grouped according to the type of research approach adopted; quantitative, qualitative or mixed-methods approach. Folders were created to organize the studies according to six categories: 1) Quantitative studies on Smart Schools (3 sources) 2) Qualitative studies on Smart Schools (3 sources) 3) Mixed-methods studies on Smart Schools (1 source) 4) Quantitative studies on 1 BestariNet (15 sources) 5) Qualitative studies on 1BestariNet (2 sources) and 6) Mixed-methods studies on 1BestariNet (1 source). Although there are many ways these sources could be categorized prior to the analysis, such as based on school level or geographical location, it is felt that by organizing the sources according to the research methodology, it would inform our current understanding of how different forms of knowledge interact with the building tasks. It is noted that research approaches are often grounded in epistemology or theory of knowledge. Post positivist tradition of data collection such as surveys and experimental research designs are based on the understanding that knowledge is out there to be discovered. This is in contrast with the social constructivist approaches involving methods such as interviews and observation where knowledge is viewed as socially constructed. As the approach taken by this review is based on discourses of knowledge, organizing the sources according to how these bodies of knowledge are arrived at is deemed appropriate. The rationale is to analyze how the discourses are built through the description of research methods and their related findings.

\section{d. Coding criteria and procedures}

The seven building tasks were established as a priori codes. Gee's (2010) discourse analysis included the following tasks: significance, building activities, building identities, building relationships, building politics, building connections, and building significance. According to Onwuegbuzie and Frels (2014) there are a number of questions that the reviewer may ask to assist the coding process. However, not all questions are relevant for the purpose of the study. Therefore, for the analysis, only the questions that are most pertinent to the purpose of the study are referred to. The criteria of tasks are presented in Table 3. 


\begin{tabular}{|c|c|c|}
\hline Task & Meaning & Questions \\
\hline Significance & $\begin{array}{l}\text { How and what different } \\
\text { elements mean with respect to } \\
\text { the many components of any } \\
\text { situation ( } p .55 \text { ) }\end{array}$ & $\begin{array}{l}\text { What are the situated meanings of some of the } \\
\text { words and phrases that seem important in the } \\
\text { situation? } \\
\text { What situated meanings and values seem to be } \\
\text { attached to places, times, people, objects, } \\
\text { artifacts, and institutions relevant in this } \\
\text { situation? }\end{array}$ \\
\hline $\begin{array}{l}\text { Building } \\
\text { activities }\end{array}$ & $\begin{array}{l}\text { Some activity or set of } \\
\text { activities as a component of a } \\
\text { situation(p.56) }\end{array}$ & $\begin{array}{l}\text { What is the larger or main activity (or set of } \\
\text { activities) during the situation? } \\
\text { What sub-activities make up this activity? }\end{array}$ \\
\hline $\begin{array}{l}\text { Building } \\
\text { identities }\end{array}$ & $\begin{array}{l}\text { Any situation that involves the } \\
\text { role of identity as a } \\
\text { consequence of an event }\end{array}$ & $\begin{array}{l}\text { What identities (roles, position) with their } \\
\text { concomitant personal, social, and cultural } \\
\text { knowledge and beliefs, feelings, and values } \\
\text { appear to be relevant to, taken for granted, or } \\
\text { under construction in the event? }\end{array}$ \\
\hline $\begin{array}{l}\text { Building } \\
\text { relationships }\end{array}$ & $\begin{array}{l}\text { Any situation whereby the } \\
\text { people involved in an event } \\
\text { enact and contract with each } \\
\text { other ( } p .56)\end{array}$ & $\begin{array}{l}\text { What sorts of social relationships seem to be } \\
\text { relevant, taken for granted, or under construction } \\
\text { in the event? How are these social relationships } \\
\text { stabilized or transformed in the situation? }\end{array}$ \\
\hline $\begin{array}{l}\text { Building } \\
\text { politics }\end{array}$ & $\begin{array}{l}\text { Any situation involves social } \\
\text { goods and views for people } \\
\text { through language }\end{array}$ & $\begin{array}{l}\text { What social goods (status, power, gender) are } \\
\text { relevant or irrelevant? And in what ways? }\end{array}$ \\
\hline $\begin{array}{l}\text { Building } \\
\text { connections }\end{array}$ & $\begin{array}{l}\text { The way situations are } \\
\text { connected or disconnected, } \\
\text { and are relevant or irrelevant } \\
\text { to each other }\end{array}$ & $\begin{array}{l}\text { What sorts of connections (looking forward or } \\
\text { backward) are made within or across utterances } \\
\text { and stretches of the interaction? }\end{array}$ \\
\hline $\begin{array}{l}\text { Building } \\
\text { significance }\end{array}$ & $\begin{array}{l}\text { Sign systems and various ways } \\
\text { of knowing that are operative, } \\
\text { oriented to, valued or devalued } \\
\text { in certain ways }\end{array}$ & $\begin{array}{l}\text { What sign systems are relevant or irrelevant in } \\
\text { the event? And how are they made relevant or } \\
\text { irrelevant? }\end{array}$ \\
\hline
\end{tabular}

Table 3: Gee's (2010) Discourse Analysis Building Tasks

A within-study analysis was conducted by applying the seven codes. Each source was read several times to identify the semantic meaning. The minimum unit of analysis employed was words and the maximum was paragraphs. A cross-case analysis was then carried out to compare and contrast the coding of Gee's building tasks. At this juncture, the coding process started with descriptive coding 
before the analytical coding by establishing the links between the categories previously identified. This has also been termed 'pattern-level coding' (Miles \& Huberman, 1994).

\section{Findings and discussion}

The discourse analysis approach based on Gee's framework enabled us to draw meaning from the research papers identified. As the study is interested in the effects of policy implementation, it is crucial that the analysis is able to yield key themes that would inform our understanding of the effects of the two different initiatives. The themes based on Gee's framework were useful to foreground the meaning of the study findings and in highlighting how the effects are similar or different. In coding the data, patterns also emerged in terms of how the themes relate to the methodological approaches used in the papers analysed.

\section{a. Teachers' perceptions of ICT in education initiatives}

This section explains the findings to answer the first research question on "What are teachers" perceptions of the Malaysian ICT in education initiatives?" There are key themes that were found to be prominent as revealed by the analysis. In answering the first research question, the analysis revealed that the building task categories, namely, significance, building activities, building identities and building significance can be respectively mapped onto the themes such as teachers' perceptions of technology, teachers' professional development and ICT use, teachers' competence in ICT use, and theoretical implications. These themes will be explained in relation to the specific building task category.

\section{The significance of teachers' perceptions of technology}

The discourse on significance was derived from the literature on teachers' perceptions of technology. As seen earlier, the government initiatives under comparison differ in terms of technological infrastructure and the modes of learning. While the Smart School project introduced physical infrastructure such as computers and projectors in the classroom, the 1BestariNet project promoted the use of cloud-based LMS in the form of Frog VLE. Another key difference is that the former attempted to introduce Smart School concepts and processes in teaching and learning whereas the latter is concerned with the implementation of e-learning and blended learning approaches.

Wan Ali et al. (2009) found many factors affected teachers' level of ICT integration in their teaching and learning. Among them include teachers' perceptions of ICT. Teachers who perceived ICT as being able to contribute to learner achievement, and whose schools were equipped with the technological infrastructure were found to integrate ICT in varying ways. Those who were less committed to ICT use and were more focused on preparing students for examinations used ICT in limited ways. The study also highlighted the challenges experienced by teachers in using the Smart School Management System (SSMS) to perform administrative work such as lesson planning and timetable setting among others. Non-functioning servers and inaccessibility of the system from home are among some of the problems cited by teachers.

The significance of teachers' perceptions is also a discourse found in Cheok's (2017) open-ended survey study on 60 teachers' perceptions of Frog VLE. Among the benefits found include the ease of organising materials using the platform and also the less need for teachers to print out materials given 
that all the materials could be accessed online via the platform. Teachers also felt that the use of the system could increase learner motivation as they have the flexibility to access the system outside the classroom. Despite these perceived benefits, there were also barriers that affected teachers' implementation. Although the study highlighted several common issues such as training, facilities and poor internet there are barriers unique to the implementation of the Frog VLE that were cited such as the language used in the system. As the system uses English language, teachers perceived it as a barrier for some teachers and students due to their low proficiency in English. The incompatibility of the system with the subject taught, such as Mathematics, is also pointed out. It was also suggested that there is a tendency for students to get distracted, and instead of browsing the recommended websites, they would browse other websites.

\section{Teachers' identity building in ICT competence and use}

Study findings based on teachers' perceptions of professional development programs informed our understanding of teachers' integration of ICT in these two contexts of policy implementation. From the Smart School studies (for example, Samuel and Abu Bakar, 2006), we could see that the teachers' identities are enacted in the discourse of findings. The identities that can be deduced by the findings are teachers who are comfortable with ICT are found to be regular users of ICT. These identities are very much tied to factors such as age and technological competencies.

The discourse in Frog VLE study findings also appears to be built on teacher identities. Cheok and Wong's (2016) case study of twelve teachers highlighted that teachers who were more comfortable with ICT tended to use it more. These teachers were younger and were more competent in ICT use. However, although these teachers were competent users, they did not necessarily use ICT in the classroom. Poor internet connection, inadequate computers and LCD were some of the constraints affecting their use.

\section{Teachers' professional development activities and teachers' ICT use}

The discourses on activity building in the studies reviewed can be categorized into activities related to teachers' professional development and how they influence their classroom teaching using technology. In the context of Smart Schools, a study by Thang, Murugujah, Lee and Azman (2010) indicated that developing teachers' skill in using ICT tools through community-based ICT activities may not necessarily be successful in helping them adopt ICT in their lessons. In their study, they examined the collaboration of 20 teachers' from different schools. Their interaction using an interactive platform was also meant to build on their ICT skills. Among the professional development activities that teachers participated in include exchanging good practice, reflection on video clips on ICT use in classroom and forum discussions. However, the analysis yielded discourses related to factors affecting their collaboration and ICT use in teaching. These include factors such as lack of time, institutional and organizational barriers and attitudinal factors.

Discourses related to activity building involving teachers' professional development in the Smart School context can also be found in Ibrahim's (2009) study. Survey data collected were based on 882 teachers' perceptions of the 14-week in-service training provided by the Ministry of Education and the in house training conducted by teachers. These training sessions focused not just on improving ICT skills but also on developing teachers' knowledge and skills on the Smart School processes which include activities, assessment and evaluation, and management of the Smart classroom. These activities were perceived by teachers as moderately successful in promoting their knowledge. However, despite the increase in their knowledge on how to implement the Smart School processes, 
teachers still found it difficult to implement them in their teaching, especially in terms of assessment and evaluation. There were a number of factors that hindered them from fully implementing the Smart approach in their teaching. Some of the factors cited include teachers' confidence in delivering Smart pedagogy, their competence in Smart Learning concepts, skills in facilitating and developing learners' critical and creative thinking, and knowledge and skills in ICT use.

Another aspect of activity building is also to do with discourses related to teachers' use of technology in the classroom. Teachers' use of technology can be viewed in terms of frequency and in terms of quality. At one level it is important to look at whether teachers used ICT regularly in the classroom. At another level, it is important to look at how they used ICT in lessons. Discourses on teachers' activities using ICT were derived from studies analyzing teachers' perceptions of ICT use. Samuel and Abu Bakar (2006) conducted semi-structured interviews with 30 English teachers from secondary and primary schools who had already received training on how to use ICT as part of the Smart School initiative. Their findings showed that only three of the teachers interviewed stated that they used ICT regularly in their lessons. There were several factors related to infrastructure that affected teachers' use of ICT in lessons. Other factors cited were to do with teachers' ICT skills.

Discourses on activity building involving Frog VLE also appear to yield a similar interpretation. Kaur and Hussein's (2015) survey involving 100 teachers from a rural district in Malaysia indicated that teachers' readiness to use Frog VLE depended highly on training. Although the teachers had been trained to use Frog VLE, they did not feel ready to use it. Thah's (2014) study which involved 426 teachers and 223 students from all over the country found that a majority of the teachers stated that they used Frog VLE for teaching and learning. However, they used them in different ways. Although Frog VLE contains a range of teaching resources, many teachers stated that they did not use the teaching resources on the platform. And although Frog VLE allows teachers to share materials or website links online, a majority of the teachers did not share teaching sites. Activity building in terms of ICT use were affected especially in rural areas by poor internet connection.

\section{Building significance of teachers' perceptions through specialized discourse}

To examine teachers' response to these policy implementations, researchers have utilised quantitative surveys. Building significance is the underlying discourse of these studies, with specialized discourse used in trying to explain teachers' response. The complexity of teachers' adoption of technology in the classroom is also captured through the use of specialized discourse. Specialized terms that represent a form of a 'sign system' relevant to the discourse are used in these studies, providing theoretical implications and contributing to the knowledge of the factors that influence teachers' response, particularly in terms of their acceptance of technology, intention to use technology and continued intention to use technology. Although these researches were conducted on certain populations of the country, they made use of established theoretical models that may enable us to predict the technology acceptance at other places. Furthermore, although the models may differ, and the explanation on the findings may not appear comparable, there are broad discourse types that can be derived from the findings. The first is to do with technological acceptance. Raman and Rathakrishnan (2018) applied the Unified Theory of Acceptance and Use of Technology (UTAUT) model (Venkatesh, Morris, Davis, \& Davis, 2003) to measure teachers' acceptance of Frog VLE. Four variables were examined: performance expectancy, effort expectancy, social influence and facility conditions. These were found to affect teachers' behavioral intention to use technology. They suggested that future research should focus on effort expectancy and to ensure that the internet is available to assist teachers to use Frog VLE. 'Effort expectancy', is one example of a specialized term relevant to the discourse, which refers to the degree of ease a user feels in using a particular system. 
In investigating teachers' acceptance of the Frog VLE technology, other researchers such as Yim, Moses and Azalea (2018) and Yim, Moses and Azalea (2019) highlighted the importance of the construct of psychological ownership which is not just about acceptance of technology but also related to a sense of empowerment and attachment to the technology. Yim et al. (2019) investigated the construct of psychological ownership in relation to the concepts of perceived usefulness and perceived ease of use, concepts that make up the Technology Acceptance Model (TAM) (Davis, 1989). The study found that although teachers may have knowledge about the technology, they may not perceive it as useful if they do not have a sense of ownership towards the technology. This points to the importance of developing teachers' sense of ownership when introducing new educational innovation. It is suggested that top-down training is not enough to enhance a sense of ownership and that a bottom-up approach that could help teachers develop a sense of ownership should be prioritized. Others such as Yunus, Kamarudin, Zachariah and Zabit (2016) looked at the theories of organization culture and service quality and how they relate to teachers' acceptance of the 1BestariNet platform. They found that service quality does not affect technology acceptance, and that organizational culture is a significant factor. However, the relationship is inverted which does not support the findings of previous studies.

Another type of discourse found within the building significance category is related to teachers' intention to use technology. For instance, Hew and Abdul Kadir (2016b) and Hew and Abdul Kadir, (2017b) utilised theories such as Channel Expansion theory and Self Determination theory to investigate teachers' intention to use Frog VLE. By utilizing such theories, new insights are obtained regarding teachers' intention to use cloud-based technology such as Frog VLE. An implication is that the technology may affect the ways teachers' intend to use. Cloud-based LMS differ from grid based LMS and the series of studies have established new theoretical perspectives regarding antecedents of use behavior and instructional effectiveness. This is different from previous studies on Frog VLE which examined behavioral intention to use and continuance intention.

Awang, Yaakob, Osman, Mukminin, and Habibi (2018) highlighted the importance of teachers' continuing to use Frog VLE, based on a survey of teachers from teaching in the suburbs and city centers district. Although there is no specific theoretical model used in the study, there are concepts that are relevant to the discourse of teachers' intention to use technology. The study highlights the importance of investigating the factors that affect teachers' intention to continue to use Frog VLE. Considering that Frog VLE accessibility depends highly on good internet connection, internet access is cited as one of the main factors for teachers' intention to continue to use the platform. The study reported that not only teachers from suburban schools had problems in terms of access but a similar finding was also obtained from teachers teaching in schools close to the main cities. The authors call for more studies exploring the rural urban digital divide and the technological infrastructure available in schools.

\section{b. The impact of ICT in education initiatives on students' learning}

To answer the second research question, "How do the Malaysian ICT in education initiatives impact students' learning?", studies that reported the effects of the policy implementation on learners' learning were analyzed. The building tasks of significance, building activities and building significance were mostly found in the studies analyzed. 


\section{Students' learning activities using ICT}

As explained earlier, the Smart School project is not just about equipping schools with technology, but also the concepts and pedagogical skills to transform classroom pedagogy. In implementing Smart School technology, teachers are supposed to also implement new forms of pedagogy. Building activities discourse is evident in these studies in the discussion of pedagogical approaches. Data from comparison of Smart Schools and mainstream schools yielded differences in terms of the pedagogical approaches adopted. Ong and Ruthven's (2010) mixed-methods study investigated whether the pedagogy used in Smart Schools helped to promote science process skills. This was done by comparing the achievements of learners and the science lessons conducted in mainstream schools and Smart schools. They found that low and average achieving students from Smart schools performed better compared to low and average achieving students from mainstream schools. The discourse appears to attribute this achievement to the pedagogical activities that were carried in the lessons based on classroom observation. While the teachers in mainstream schools emphasized on note taking and the use of textbooks, the Smart School teachers used technology in the delivery of lessons. The technological environment appeared to also contribute to the differences in terms of classroom activities. Smart School teachers did not only promote the use of ICT but also other Smart pedagogies. Smart School teachers made use of the preloaded software which helped students to explore the materials such as hyperlink videos and animations. Peer support was also evident in the Smart Schools through pair work and group work. But there was limited student interaction to promote knowledge construction in mainstream schools. It appears that the activities involving technology in the Smart Schools led to student-centered learning.

The discourse on learners' learning within the Frog VLE environment also appears to highlight the positive role of the platform. One example is Ramasamy and Abdul Aziz's (2018) experimental study in the context of English language teaching. The experimental group was required to assess their peers' writing using the materials uploaded on Frog VLE for eight lessons whereas the control group received regular instruction in the classroom. They were guided by the teachers on how to use these materials. They were found to have performed better than the control group on their descriptive writing as indicated by the significant difference between the pre and post tests. An implication of the study is that the appropriate uses of the platform can result in enhanced student learning.

\section{The significance of students' perceptions of ICT}

Kamalludeen, Hassan and Ahmad Nasaruddin's (2016) study on secondary school students' use of Frog VLE found that students perceived the platform to facilitate their own learning process and that they developed their ICT skills as a result of regular use of the platform. The study also shows that teachers' use of Frog VLE prompted learners' interest to use the platform. This highlights the need for teachers to actively use such platforms in their teaching to instill students' interest in accessing and exploring learning materials available on the platform on their own. The discourse observed in Abdul Majid and Che Hasim's (2019) study similarly highlights the crucial role of teachers. Their study shows that students became more interested in learning when their teachers integrated Frog VLE and used the interactive learning materials accessible through the platform in their teaching.

\section{Building significance of students' perceptions through specialized discourse}

Specialized discourse that builds on the significance of students' perceptions is observed in studies looking at learners' perceptions or attitudes. The concept of learner attitudes, for example, has been discussed extensively in the educational literature and specific constructs have been proposed to 
explain attitudes. Student attitudes are important to explore in the context of ICT use as they contribute to our understanding of the factors that contribute to an ICT program's success or failure. Ong and Ruthven (2009) looked at student attitudes towards science by comparing Smart School and mainstream school students. Utilizing the Malay version of the Attitudes Towards Science in School Assessment (ATSSA) questionnaire, they found that students from the Smart Schools had a more positive attitude towards science compared to their peers from the mainstream schools. They attributed this finding to the pedagogical approach adopted by these Smart Schools which not only emphasized the use of ICT but also the Smart pedagogy such as a constructivist approach to learning science including self-accessed, self-paced and self-directed learning. They recommended that future research should focus on specific features of Smart School and identify the features that have the most impact on student attitudes towards science.

Studies on learners' perceptions also commonly utilized theoretical models. The discourse derived from these studies indicate the importance of particular constructs to explain the phenomenon of learners' acceptance and use of technology. These studies, however, were mostly on learners' perceptions of Frog VLE. For instance, Lim, Mohamad Said, Atan and Ler (2018) investigated 30 Science students and 30 Arts students' perceptions using a questionnaire that linked the Diffusion of Innovations Theory (DOI) and Technology Acceptance Model (TAM). The constructs of advantages, compatibility, complexity and observation from DOI theory were found to be correlated with students' Perceived Usefulness and Perceived Ease-of-Use (concepts from TAM) of Frog VLE. Abdul Majid and Che Hasim's (2019) study on the perceptions of 315 primary school students from an urban district on Frog VLE was also guided by TAM and linked to Technology Readiness Index (TRI). The discourse found in this study also appears to support the role of Frog VLE in enhancing learners' learning. They perceived that the use of Frog VLE helped to improve their understanding of subject matter and their academic performance. Learners' perceived usefulness of the platform implies that such technology can be utilized in teaching and learning with appropriate pedagogical strategies.

\section{Conclusion and recommendations}

The discourse analysis approach undertaken in this study yielded a contextualized understanding of ICT in education initiatives. In comparing the two policy initiatives using the approach, not only are the common issues highlighted but also the unique issues that are specific to the particular ICT policy initiative and the reasons for its successful or unsuccessful implementation. The application of DARS enabled the pertinent discourses to be foregrounded through the different building tasks or discourse categories. We note that teachers' responses to the two different ICT in education initiatives are tied to aspects such as teachers' professional development activities and their competence in and use of ICT. The impact of these initiatives on students' learning are also made clearer through the analysis as we discover the types of learning that took place as a result of their implementation and their effect on students' achievement. However, there are unique differences that were derived from the comparison. This is due to the type of technology and the type of pedagogical approach promoted by the two different initiatives.

The current study also demonstrated the applicability of the DARS framework within the context of ICT in education. We have shown how the building task categories can be used to analyze the discourse of ICT in education initiatives based on research findings in the Malaysian setting. Nevertheless, these categories should not be viewed as compartmentalized, separate from each other. While each building task category has its own distinct focus, the discourses underlying each category appear to be connected. For example, the building task of significance in terms of teachers' perceptions of 
technology is closely tied to building activities or the ways teachers implement technology in the classroom. It is beyond the scope of this paper to illustrate how these building tasks relate to each other in the context of ICT in education. However, the current study has paved the way for future research to pursue this line of investigation further. Research into this area may also apply a discourse analysis approach through a more detailed comparison of the texts to establish the connections between the building task categories. Such approach may involve looking at the local features of the text such as the sentences or phrases used.

Another conclusion that can be drawn from the analysis is the emphasis given by the different building tasks. While some of the building task categories are more practical in their emphases (for example, the building tasks of significance and building activities), and requiring a more practical response and action from the relevant parties, other building tasks appear to highlight a specialized scholarly discourse on technology adoption. The discourses on building significance were mainly found either in studies grounded in theoretical models or studies that made use of specialized concepts. Although practical implications can also be drawn from these studies, an important contribution of these studies is the theoretical implications and how they contribute to the ongoing discourse in their relative fields. The findings from these studies are important in their contribution to knowledge within a specialized discourse area. These include factors that predict the behavior, intention to use and intention to continue to use. We also note that although some of the building task categories such as building politics and building connections were not highlighted in this study, it does not imply that these discourse categories are not relevant in discussions of ICT in education initiatives. These discourse types were in fact found in some cases, particularly in studies focusing on teachers' professional development. However, as they do not make up the dominant discourse of the majority of the studies reviewed, these building task categories are not discussed in this study. Nevertheless, future research may wish to adopt a within-study approach and examine only selected few articles on a specific aspect, such as professional development, and analyze their underlying discourse to help us better understand a particular discourse type within that aspect.

In terms of methodological implications, the different methodological approaches adopted in the studies reviewed appear to influence our analysis. In looking at teachers' perceptions, the research studies have utilized both quantitative and qualitative methods. Generally, in examining teachers and students' perceptions, studies utilizing quantitative procedures would refer to theoretical frameworks to identify the variables to be examined. A majority of the studies reviewed fall into this category. In contrast, qualitative studies utilized theoretical frameworks as a guide to explore teachers and students' perceptions. However, a closer look to the literature reveals gaps that need to be filled, especially in the context of student learning. We note that there are limited studies that have utilized experimental/non-experimental methods in investigating students' learning in both the Smart School and the Frog VLE contexts. What is also noted is that qualitative studies investigating classroom teaching processes are lacking. Therefore, more such research is needed to understand how ICT education policy initiatives impact students' learning. Future research into this area may also wish to look at students' learning within specific subject domains. The studies reviewed here only looked at the subjects of science and English. Also, as some of the studies have shown, further research is needed to understand how teachers from rural and urban areas respond to ICT in education policy implementation and how this affects students' learning. It is also recommended that future research looking at policy implementation includes a focus on teachers' professional development considering that this aspect has not been given much emphasis by previous research studies in the context of the two initiatives.

Analyzing the literature using building tasks also helps to link knowledge and action. More often than not, research findings tend to be regarded as falling exclusively within the domain of scholarly work and the purview of academics. Despite the wealth of findings that can be drawn from the literature on 
the impact of ICT in education policy, it can be difficult for policy makers to utilize the findings available due to the differing research scope and foci. The findings from the discourses analyzed can serve as a guidance for policy makers in developing strategic action plans to address the issues highlighted. By looking at these issues from the perspective of building tasks, policy makers can address them in a more efficient and targeted manner. Some building tasks are clearly more prominent than others and this can perhaps highlight the areas that are more pressing to be addressed. Policy makers can also adopt the building tasks as a framework to organize their strategic plans in tackling the issues highlighted. As shown by the analysis, there are areas where the implementation of an ICT education initiative can be considered as a success. This success should be built on and further enhanced in the implementation of future policies. However, there are also areas where challenges of implementation occurred. These will need to be carefully looked into to avoid being repeated in the implementation of future ICT in education policies.

In sum, Gee's discourse analysis as the guiding framework used in this study has been useful in achieving the purpose of the study which is to explore the impact of the ICT policy initiatives on teachers and students. Through the adoption of the DARS approach in the analysis of research findings, we obtain a contextualized understanding of the issues surrounding large-scale ICT in education policy initiatives. This study has demonstrated that technical support in schools, training for teachers in technology-mediated classrooms and a sense of technology ownership are among the critical factors for student achievement and program success. It is also vital to remember that technology is only a tool used in delivery of content. In order for meaningful learning to take place, teachers still need to have content and pedagogical knowledge to implement ICT-based lessons.

\section{References}

Abdul Majid, R., \& Che Hasim, J. (2019). The effectiveness of Frog VLE implementation: students' perspective. Indonesian Journal of Electrical Engineering and Computer Science, 14(1), 381387.

Awang, H., Aji, Z. M., Yaakob, M. F. M., Osman, W. R. S., Mukminin, A., \& Habibi, A. (2018). Teachers' intention to continue using Virtual Learning Environment (VLE): Malaysian context. JOTSE, 8(4), 439-452.

Chan, F. M. (2002, October). ICT in Malaysian schools: Policy and strategies. Paper presented at a Workshop on the Promotion of ICT in Education to Narrow the Digital Divide, Tokyo, Japan

Cheok, M. L., \& Wong, S. L. (2016). Frog virtual learning environment for Malaysian schools: Exploring teachers' experience. In R. Huang, J. Kinshuk, \& K. Price (Eds.) ICT in education in global context: Comparative reports of innovations in $K-12$ education (pp. 201-209). Springer.

Coppola, E. M. (2004). Powering up: Learning to teach well with technology. Teachers College Press.

Dale, R. (1986) Perspectives on Policy Making, in Module 1. Introducing Education Policy: principles and perspectives. Open University Press.

Davies, F. (1989). Perceived usefulness, perceived ease of use, and user acceptance of information technology. MIS Quarterly, 13(3), 319-340.

Eickelmann, B., \& Vennemann, M. (2017). Teachers' attitudes and beliefs regarding ICT in teaching and learning in European countries. European Educational Research Journal, 16(6), 733-761. 
Ertmer, P. A. (1999). Addressing first-and second-order barriers to change: Strategies for technology integration. Educational Technology Research and Development, 47(4), 47-61.

Eteokleous, N. (2008). Evaluating computer technology integration in a centralized school system. Computers \& Education, 51(2), 669-686.

Gee, J. P. (2010). An introduction to discourse analysis: Theory and method (2nd ed.). Routledge.

Greene, J. C. (2007). Mixed methods in social inquiry (Vol. 9). John Wiley \& Sons.

Hamilton, J., \& Feldman, J. (2014). Planning a program evaluation: Matching methodology to program status. In J.M. Spector, M.D. Merrill, J. Elen, \& M. J. Bishop (Eds.), Handbook of research on educational communications and technology (pp. 249-256). Springer.

Hawkey, R. (2006). Impact theory and practice. Studies in language testing. Cambridge University Press and UCLES.

Hew, T. S., \& Kadir, S. L. S. A. (2016a). Understanding cloud-based VLE from the SDT and CET perspectives: Development and validation of a measurement instrument. Computers \& Education, 101, 132-149.

Hew, T. S., \& Kadir, S. L. S. A. (2016b). Behavioural intention in cloud-based VLE: An extension to Channel Expansion Theory. Computers in Human Behavior, 64, 9-20.

Hew, T. S., \& Syed A. Kadir, S. L. (2017a). Applying Channel Expansion and Self-Determination Theory in predicting use behaviour of cloud-based VLE. Behaviour \& Information Technology, 36(9), 875-896.

Hew, T. S., \& Kadir, S. L. S. A. (2017b). The drivers for cloud-based virtual learning environment: Examining the moderating effect of school category. Internet Research, 27(4), 942-973.

Howley, A., Wood, L., \& Hough, B. (2011). Rural elementary school teachers' technology integration. Journal of Research in Rural Education, 26(9), 1-13.

Ibrahim, M. S. (2009). An evaluation of the Smart School teacher training programme and its impact on integrating technology into teaching and learning processes in Malaysia. SOSIOHUMANIKA, $2(2), 253-280$.

Kale, U., \& Goh, D. (2014). Teaching style, ICT experience and teachers' attitudes toward teaching with Web 2.0. Education and Information Technologies, 19(1), 41-60.

Kaur, T., \& Hussein, N. (2015). Teachers' readiness to utilize Frog VLE: A case study of a Malaysian secondary school. Journal of Education, Society and Behavioural Science, 20-29.

Kormos, E. M. (2018). The unseen digital divide: Urban, suburban, and rural teacher use and perceptions of web-based classroom technologies. Computers in the Schools, 35(1), 19-31.

Kozma, R. B. (2008). Comparative analysis of policies for ICT in education. In J. Voogt \& G. Knezek (Eds.), International handbook of information technology in primary and secondary education (pp. 1083-1096). Springer.

Lam, Y. (2000). Technophilia vs. technophobia: A preliminary look at why second language teachers do or do not use technology in their classrooms. Canadian Modern Language Review, 56, 389410.

Lim, W. K., Said, M. N. H. M., Atan, N. A., \& Ler, S. Y. (2018). Students' perception towards the use of Frog VLE based on Rogers' Diffusion of Innovation theory. Innovative Teaching and Learning Journal (ITLJ), 2(1), 51-57. 
Mai, M. Y., \& Muruges, G. R. (2018). Primary school science teachers' attitude towards using virtual learning environment (VLE) in teaching science. European Journal of Education, 1(3), 155-162.

Miles, M.B., \& Huberman, A.M. (1994). Qualitative data analysis: A sourcebook of new methods (2nd edition). Sage.

Multimedia Development Corporation (MDC) (2005). Malaysian Smartschool Roadmap 2005-2020:An Educational Odyssey. Putrajaya. Government of Malaysia

Mumtaz, S. (2000). Factors affecting teachers' use of information and communications technology: a review of the literature. Journal of Information Technology for Teacher Education, 9(3), 319342.

Ong, E. T., \& Ruthven, K. (2012). The effectiveness of Smart schooling in terms of student achievement in science: A study of Malaysian practice. Education, 35(1), 1-21.

Ong, E. T., \& Ruthven, K. (2010). The distinctiveness and effectiveness of science teaching in the Malaysian 'Smart school'. Research in Science \& Technological Education, 28(1), 25-41.

Ong, E. T., \& Ruthven, K. (2009). The effectiveness of Smart schooling on students' attitudes towards Science. Eurasia Journal of Mathematics, Science \& Technology Education, 5(1), 35-45.

Onwuegbuzie, A. J., \& Frels, R. K. (2014). A framework for using discourse analysis for the review of the literature in counseling research. Counseling outcome research and evaluation, 5(1), 52-63.

Ottenbreit-Leftwich, A. T., Glazewski, K. D., Newby, T. J., \& Ertmer, P. A. (2010). Teacher value beliefs associated with using technology: Addressing professional and student needs. Computers \& Education, 55(3), 1321-1335.

Ozga, J. (2000). Policy research in educational settings. Open University Press.

Pelgrum, W. J. (2001). Obstacles to the integration of ICT in education: Results from a worldwide educational assessment. Computers \& Education, 37(2), 163-178.

Pettersson, F. (2018). On the issues of digital competence in educational context - a review of literature. Education and Information Technologies, 23(3), 1005-1021.

Phillips, N., \& Hardy, C. (2002). Discourse analysis: Investigating processes of social construction (Vol. 50). Sage Publications.

Plomp, T., Anderson, R. E., Law, N., \& Quale, A. (Eds.). (2009). Cross-national information and communication technology policies and practices in education (2nd ed.). IAP.

Raman, A., \& Rathakrishnan, M. (2018). Frog VLE: Teachers' technology acceptance using UTAUT model. International Journal of Mechanical Engineering and Technology, 9(3), 529-538.

Ramasamy, R. M. M., \& Aziz, A. B. A. (2018). Peer assessment in writing using Frog VLE in a secondary school ESL classroom. Creative Education, 9(14), 2265-2279.

Samuel, R., \& Bakar, Z. (2006). The utilization and integration of ICT tools in promoting English language teaching and learning: Reflections from English option teachers in Kuala Langat District, Malaysia. International Journal of Education and Development using ICT, 2(2), 4-14.

Snoeyink, R., \& Ertmer, P. A. (2001). Thrust into technology: How veteran teachers respond. Journal of Educational Technology Systems, 30(1), 85-111.

Thah, S. S. (2014). Leveraging virtual learning environment to scale up quality teaching and learning in Malaysia. Asia-Pacific Collaborative Education Journal, 10(1), 1-17. 
Thang, S. M., Murugaiah, P., Lee, K. W., Azman, H., Tan, L. Y., \& Lee, Y. S. (2010). Grappling with technology: A case of supporting Malaysian Smart School teachers' professional development. Australasian Journal of Educational Technology, 26(3), 400-416.

Taylor, S., Risv I, F., Lingard, B. \& Henry, M. (1997) Educational Policy and the Politics of Change. Routledge.

Tolani-Brown, N., McCormac, M., \& Zimmermann, R. (2011). An analysis of the research and impact of ICT in education in developing country contexts. In J. Steyn \& G. Johanson (Eds.), ICTs and sustainable solutions for the digital divide: Theory and perspectives (pp. 218-242). IGI Global.

Lim, W. K., Said, M. N. H. M., Atan, N. A., \& Ler, S. Y. (2018). Students' perception towards the use of Frog VLE based on Rogers' Diffusion of Innovation Theory. Innovative Teaching and Learning Journal (ITLJ), 2(1), 51-57.

Venkatesh, V., Morris, M. G., Davis, G. B., \& Davis, F. D. (2003). User acceptance of information technology: Toward a unified view. MIS Quarterly, 27(3), 425-478.

Wood, L., \& Howley, A. (2012). Dividing at an early age: the hidden digital divide in Ohio elementary schools. Learning, Media and Technology, 37(1), 20-39.

Yeop, M. A., Yaakob, M. F. M., Wong, K. T., Don, Y., \& Zain, F. M. (2019). Implementation of ICT policy (blended learning approach): Investigating factors of behavioural intention and use behaviour. International Journal of Instruction, 12(1), 767-782.

Yim, J. S. C., Moses, P., \& Azalea, A. (2019). Predicting teachers' continuance in a virtual learning environment with psychological ownership and the TAM: A perspective from Malaysia. Educational Technology Research and Development, 67(3), 691-709.

Yim, J. S. C., Moses, P., \& Azalea, A. (2018). Effects of psychological ownership on teachers' beliefs about a cloud-based virtual learning environment. Research and Practice in Technology Enhanced Learning, 13(1), 13.

Younie, S. (2006). Implementing government policy on ICT in education: Lessons learnt. Education and Information Technologies, 11(3-4), 385-400.

Yunus, N. K. Y., Kamarudin, M. H., Zachariah, T. Z., \& Zabit, M. N. M. (2016). Service quality, organisational culture, and technology acceptance towards 1BestariNet application in northern Malaysia. International Business Education Journal (IBEJ), 9(1), 16-26.

Zhao, Y., Pugh, K., Sheldon, S., \& Byers, J. L. (2002). Conditions for classroom technology innovations. Teachers College Record, 104(3), 482-515. 